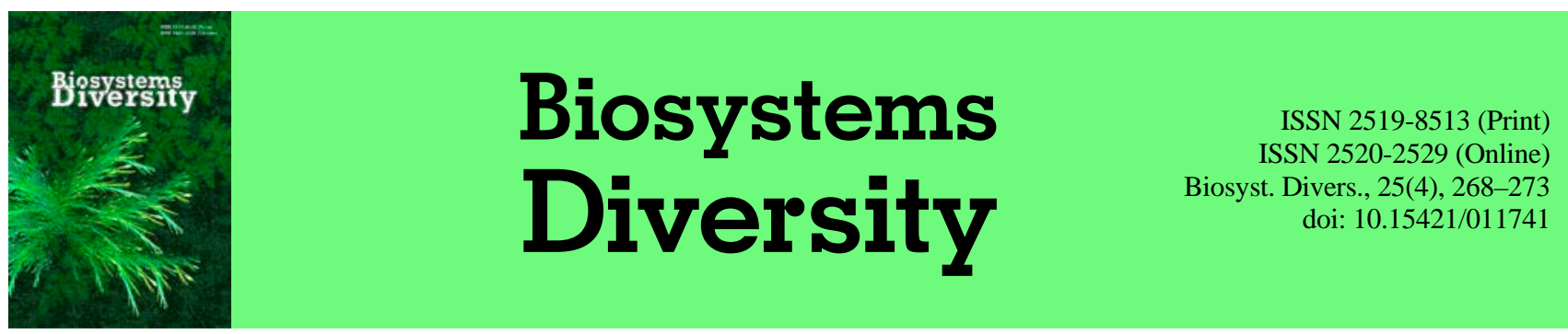

\title{
Reaction of photosynthetic apparatus of a representative of extrazonal steppe plants Quercus robur to air pollution by motor vehicle emissions
}

\author{
L. V. Shupranova*, Y. V. Lykholat*, N. O. Khromikh*, Z. V. Grytzaj*, A. A. Alexeyeva*, V. S. Bilchuk** \\ *Oles Honchar Dnipro National University, Dnipro, Ukraine \\ **Dnipro Medical Academy, Dnipro, Ukraine
}

Article info

Received 18.10.2017

Received in revised form 10.11.2017

Accepted 14.11.2017

Oles Honchar Dnipro National University, Gagarin ave., 72, Dnipro, 49010, Ukraine. Tel.: +38-097-408-25-02 E-mail:ecohous@ukr.net

Dnipro Medical Academy, Vernadskij st.,9, Dnipro, 49044, Ukraine.

Tel.: +38-096-352-56-82

E-mail:

valentinabilchuk@gmail.com
Shupranova, L. V., Lykholat, Y. V., Khromikh, N. O., Grytzaj, Z. V., Alexeyeva, A. A., \& Bilchuk, V. S. (2017). Reaction of photosynthetic apparatus of a representative of extrazonal steppe plants Quercus robur to air pollution by motor vehicle emissions. Biosystems Diversity, 25(4), 268-273. doi:10.15421/011741

We examined the vital condition of the common oak (Quercus robur L.) in plantations of different categories in Dnipro-city. In the investigated plantations, differences in the individual resistance of plants were recorded. The patterns of changes in the pigmented complex of leaves exposed to atmospheric pollution from motor vehicle emissions were studied in connection with the life state of oak trees. The content of chlorophyll $a$ had, in all variants of the experiment, significantly higher values than chlorophyll $b$. Chlorophyll $a$ accounted for 52.4-75.0\% of the total content of chlorophylls, and chlorophyll $b$ (25.0-47.6\%). Regardless of the level of air pollution, relatively healthy oak plants were characterized by a high content of pigments activity in the photosynthetic apparatus of the leaves. A chronic moderate influence of motor vehicle emissions had a positive effect on the content of green pigments and carotenoids. Increase in the intensity of transport emissions resulted in a significant reduction in the accumulation of chlorophylls and to an increase in carotenoids. The stability of the chlorophyll $a$ / chlorophyll $b$ ratio under the influence of motor vehicle emissions was been registered. Only severely damaged common oak trees showed a decrease of this parameter by 29.3\% compared with healthy and moderately weakened specimens of oak. The values of the coefficients of variation in the content of chlorophylls, their amounts and ratios, as well as carotenoids were low and represent less than $19.0 \%$, while the amplitude of the variability of the studied parameters of the pigment complex, depending on the life state of plants and the intensity of transport emissions, was quite significant: the highest fluctuations in the content indexes were recorded for chlorophyll $a$, the sum of chlorophylls $a+b$ in trees from the park area and the area with a medium level of pollution, chlorophyll $b$ only in oaks from the street with an average level of air pollution by transport emissions. The smallest variability was a characteristic of the ratio of chlorophylls $a / b$ and the content of carotenoids. Low values of the ratio of the sum of chlorophylls $a+b$ to carotenoids (4.3-5.2) indicate the stress state of oak plants in urban environments.

Keywords: motor vehicle emissions; life state; oak pedunculate; photosynthetic pigments; variability

\section{Реакція фотосинтетичного апарату представника екстразональної рослинності степу Quercus robur на забруднення атмосфери транспортними емісіями}

\author{
Л. В. Шупранова*, Ю. В. Лихолат*, Н. О. Хромих*, 3. В. Грицай*, А. А. Алексєєва*, В. С. Більчук** \\ *Дніпровський національний університет імені Олеся Гончара, Дніпро, Украӥна \\ **Дніпровська медична академія, Дніпро, Украӥна
}

Визначено життєвий стан дерев дуба звичайного (Quercus robur L.) у насадженнях різних категорій м. Дніпро. У досліджених насадженнях зареєстровано відмінності в індивідуальній стійкості рослин. Вивчено закономірності змін у пігментному комплексі листя в умовах забруднення атмосфери викидами автотранспорту та у зв’язку із життєвим станом дерев дуба. Вміст хлорофілу $а$ за всіх варіантів досліду має набагато вищі значення, ніж хлорофіл $b$. На хлорофіл $a$ припадає $52,4-75,0 \%$ від загального вмісту хлорофілів, а на хлорофіл $b-$ 25,0-47,6\%. Незалежно від рівня забруднення повітря полютантами, відносно здоровим рослинам дуба притаманна висока за вмістом пігментів активність фотосинтетичного апарату листків. Помірний хронічний вплив викидів автотранспорту мав позитивний ефект на вміст зелених пігментів і каротиноїдів. Підвищення рівня інтенсивності транспортних емісій викликало суттєве зниження акумуляції хлорофілів та підвищення каротиноїдів. Зареєстровано стабільність співвідношення хлорофіл $a$ / хлорофіл $b$ за впливу викидів автотранспорту. Тільки сильно пошкоджені дерева дуба звичайного показали зниження цього параметра на 29,3\% порівняно зі здоровими та ослабленими екземплярами. Значення коефіцієнтів варіації вмісту хлорофілів, їх суми та співвідношення, а також каротиноїдів невисокі та складають менше $19 \%$, у той час як амплітуда мінливості вивчених параметрів пігментного комплексу залежно від життєвого стану рослин та інтенсивності транспортних емісій доволі суттєва: найбільші коливання показників вмісту зареєстровані для хлорофілу $а$, суми хлорофілів $a+b$ у дерев із паркової зони та території із середнім рівнем забруднення, а хлорофілу $b$ тільки у дубів із вулиці із середнім 
рівнем забруднення атмосфери транспортними емісіями. Найменша варіабельність притаманна показнику співвідношення хлорофілів $a / b$ і вмісту каротиноїдів. Низькі значення співвідношення суми хлорофілів $a+b$ до каротиноїдів $(4,3-5,2)$ свідчать про стресовий стан рослин дуба в умовах міського середовища.

Ключові слова: автотранспортні викиди; життєвий стан; дуб звичайний; фотосинтетичні пігменти; мінливість

\section{Вступ}

Індустріальне м. Дніпро розташоване на півночі степової зони України, де функціонування всіх елементів екосистем: рослини (Lykholat et al., 2016a, 2017; Dzhygan, 2017), тварини (Brygadyrenko, 2016) та людина (Lykholat et al., 2016b; Yermishev et al., 2017) зазнає негативного впливу кліматичних особливостей регіону. Дія несприятливих факторів на рослини, в першу чергу, зумовлює пошкодження асиміляційного апарату, скорочення вегетації, зниження інтенсивності ростових і генеративних процесів, порушення метаболізму, а також зменшення тривалості життя міських насаджень (Volodarets, 2012; Stojnić, 2016). Основні джерела техногенного забруднення у великих містах України - промислові та автотранспортні викиди. В Україні автотранспорт дає приблизно $30-40 \%$ усього забруднення атмосфери (Vas'kin and Vas'kina, 2009). Викиди забруднювальних речовин автомобільним транспортом у середньому за рік складають близько 5,5 млн т (39\% об'єму викидів в Україні). У великих містах забруднення повітря вихлопними газами іноді досягає $70-90 \%$ загального рівня забруднення. Тому проблема нейтралізації шкідливих речовин за допомогою рослин актуальна та потребує визначення функціональних реакцій деревних видів за різного ступеня забруднення атмосфери 3 метою встановлення їх адаптивного потенціалу та передбачення оптимальних шляхів їх використання в насадженнях різного призначення.

Активність фотосинтетичного апарату листя рослин у несприятливих умовах середовища розглядається як одна з інтегральних характеристик їх адаптації, рівень якої часто визначається за рівнем асиміляції $\mathrm{CO}_{2}$, змиканням продихів, вмістом пігментів у листках (Nail et al., 2008; Xu and Zhou, 2008; Favaretto et al., 2011; Dai et al., 2012; Castro et al., 2015). Зниження вмісту хлорофілу використовують як індикаторну реакцію пошкодження, що відбувається за дії забруднювальних речовин (Dzhygan, 2017). Натомість низка науковців показують неоднозначність реакції відповіді пігментного апарату різних видів деревних рослин на вплив стресових факторів фітотоксикантів (Korshykov, 1995; Volodarets, 2011; Sehmer, 2012).

Дуб звичайний (Quercus robur L.) належить до стійких до умов посухи та урбогенного середовища порівняно з такими як Aesculus hippocastanum L., Picea abies L. тощо (Lykholat et al., 2016a; Stojnić et al., 2016). Ця порода культивується в паркових зонах міста Дніпро та уздовж автотранспортних магістралей. Дослідження функціонального стану цієї породи в умовах викидів автотранспорту в степовій зоні України досить обмежені та стосуються, як правило, санітарного стану дуба звичайного та мінливості деяких морфологічних ознак. Недостатньо спостережень за реакціями рослин дуба різного життєвого стану за постійного впливу забруднення атмосфери полютантами в урбаністичних екосистемах. Маловивченим залишається питання внутрішньовидової мінливості вмісту фотосинтетичних пігментів за дії несприятливих факторів довкілля, а це становить не тільки теоретичний, а і практичний інтерес, оскільки дозволяе виявляти найстійкіші особини з метою використання їх насіннєвого потомства як у практиці зеленого будівництва, так і в селекції.

Мета цієї статті - оцінити вплив забруднення атмосфери міста викидами автотранспорту різної інтенсивності на вміст та мінливість хлорофілів і каротиноїдів у листках дерев дуба звичайного різного життєвого стану.

\section{Матеріал і методи досліджень}

У зелених насадженнях м. Дніпро як об’єкт досліджень виділені три групи модельних дерев дуба звичайного (Quercus robur L.) 20-30-річного віку із близькими морфолого-таксаційними ознаками, які зростають в умовах впливу викидів автотранспорту (рис. 1).

Ділянка 1 локалізована в Центральному парку імені Т. Г. Шевченка (4827’41”' N, 3504'15’' Е, висота над рівнем моря - 82,5 м). Дубове насадження - в центральній частині парку на відстані 100 м від автошляху з низькою інтенсивністю руху автотранспорту ( 3,1 тис. автомобілів на добу).

Ділянка 2 локалізована у примагістральному насадженні дуба звичайного в районі ПМЗ на вул. Кедріна $\left(48^{\circ} 26^{\prime} 28^{\prime}\right.$ ' N, $35^{\circ} 00^{\prime} 06^{\prime \prime}$ Е), де визначена середня інтенсивність руху автотранспорту (7,44 тис. автомобілів на добу).

Ділянка 3 розташована у невеликій зеленій зоні ДК Машинобудівників на вул. Робітничій (48²6’46”' N, 3459'58', E; відмітка висоти місцевості над рівнем моря - 160 м) на незначній відстані (1,75 км у північному напрямку) від центральної прохідної Південного машинобудівного заводу (ПМЗ) з високою інтенсивністю автонавантаження (21,3 тис. автомобілів на добу).

Досліджені ділянки характеризуються середніми та легкими суглинками 3 умістом гумусу $1,0-4,0 \%$, а також присутністю важких металів (Pb, Cd) у грунті (Dolhova and Filina, 2003). Найменша концентрація важких металів властива грунту з паркової зони міста (Pasichnyy and Serdyuk, 2002).

Листя середньої формації по 15 штук відбирали на річному вегетативному прирості з нижньої третини крони південної експозиції в суху ясну погоду в середині липня 2015 року від шести дерев дуба звичайного одночасно 3 кожної вивченої ділянки.

Життєвий стан дуба звичайного встановлювали візуально за ступенем пошкоджень асиміляційного апарату та крон рослин: кількість живих гілок у кронах дерев; кількість живих (без некрозів) листків у кронах; пігментацію листків; наявність хлорозів і некрозів, пошкоджень хворобами та шкідниками.

У лабораторних умовах у листі дуба звичайного визначали вміст хлорофілів $a$ і $b$ і сумарних каротиноїдів спектрофотометричним методом в ацетонових екстрактах за довжиною хвиль поглинання 663 нм (хлорофіл $a$ ), 645 нм (хлорофіл $b$ ) і 440,5 нм (каротиноїди). Концентрацію пігментів розраховували за рівнянням Wettstein (1957) і виражали в мг/г сирої речовини.

Порівняння вибірок середніх значень здійснювали, розраховуючи коефіцієнт Фішера за програмою ANOVA у пакеті Statgrafs і застосовували критерій достовірної різниці групових середніх Тьюкі (Honestly Significant Difference). Відмінності були визнані статистично значущими за $\mathrm{P}<0,05$.

\section{Результати}

Основну кількість досліджених дерев віднесено до I (відносно здорові - 57,9\%) і II (ослаблені - 26,3\%) класів життєвості. На кожній ділянці, включаючи паркову зону, зростають дерева дуба з III класом життєвості (сильно пошкоджене 15,8\%). На території парку дерева, віднесені до I класу життєвості, на листках мали невелику кількість хлорозів, пожовтіння тканини листка $(5,2-6,1 \%)$, наявність точкових змін пігментації (жовті точки - 8,3-9,1\%) та невелику кількість крайових некрозів. Траплялись ураження листків борошнистою росою. У сильно пошкодженого дерева (III клас життєвості) відмічено зниження густоти облиствлення крони, виключення з асиміляційної діяльності 60,4\% площі листків через ураження борошнистою росою.

Листя сильно пошкодженого дерева з вулиці із середньою інтенсивністю руху транспорту виявилось також ураженим борошнистою росою $(18,1 \%)$, відмічалось більше, порівняно 3 листям дуба з паркової зони, ураження хлорозами (12,3\%), крайовими некрозами $(15,1 \%)$ та змінами пігментації (червоні 
та сині точки, жовті та червоні плями - 25,2\%). Ослаблені дерева дуба (II клас життєвості) мали зрідження скелетної частини крони, наявність до 30,3\% мертвих і засохлих гілок. Зареєстровано чіткі відмінності за ступенем ураження листків між деревами, які зростають у парковій зоні та у примагістральних насадженнях. Для дерев паркової зони характерна невелика наявність хлорозів і некрозів. Порівняно з деревами дуба паркової зони на листках дерев із вуличних насаджень поряд із крайовими некрозами з'являються міжжилкові (8,5\%) та білышою мірою уражені борошнистою росою $(18,1 \%)$, а у дерев, які зростають на території із середньою інтенсивністю руху автотранспорту, відмічаються ураження листків шкідниками (об’їдання та скелетування листків).

Таким чином, у насадженнях дуба звичайного спостерігали помітні відмінності індивідуальної стійкості рослин, що сприяє вивченню внутрішньовидових відмінностей їх метаболізму в умо- вах забруднення атмосфери вихлопними газами автотранспорту. Із метою з'ясування наслідків впливу викидів автотранспорту різної інтенсивності на функціональний стан дерев дуба звичайного різної життєвості визначали зміни вмісту та співвідношення фотосинтетичних пігментів. Для оцінки значущості відмінностей між середніми груповими значеннями застосовували критерій Тьюкі. Результати дисперсійного аналізу залежності вмісту пігментів листкової пластинки дуба звичайного від життєвого стану дерев і рівня атмосферного забруднення емісіями автотранспорту виявили значимі відмінності за $\mathrm{P}<0,005$ (табл.). У парковій зоні листки дуба звичайного I класу життєвості містили хлорофіли $a$ i $b$, a їх суми достовірно у більших кількостях порівняно з II і III класами: хлорофілу $а$ на 27,6\% і 44,3\% ( $\left.\mathrm{F}=108,37 ; \mathrm{P}<3,2 \cdot 10^{-6}\right)$, хлорофілу $b$ на $28,2 \%$ і $21,1 \%\left(\mathrm{~F}=14,75 ; \mathrm{P}<1,5 \cdot 10^{-4}\right)$, їх суми на $28,6 \%$ i 34,0\% (F = 50,26; $\left.\mathrm{P}<2,1 \cdot 10^{-5}\right)$ відповідно.

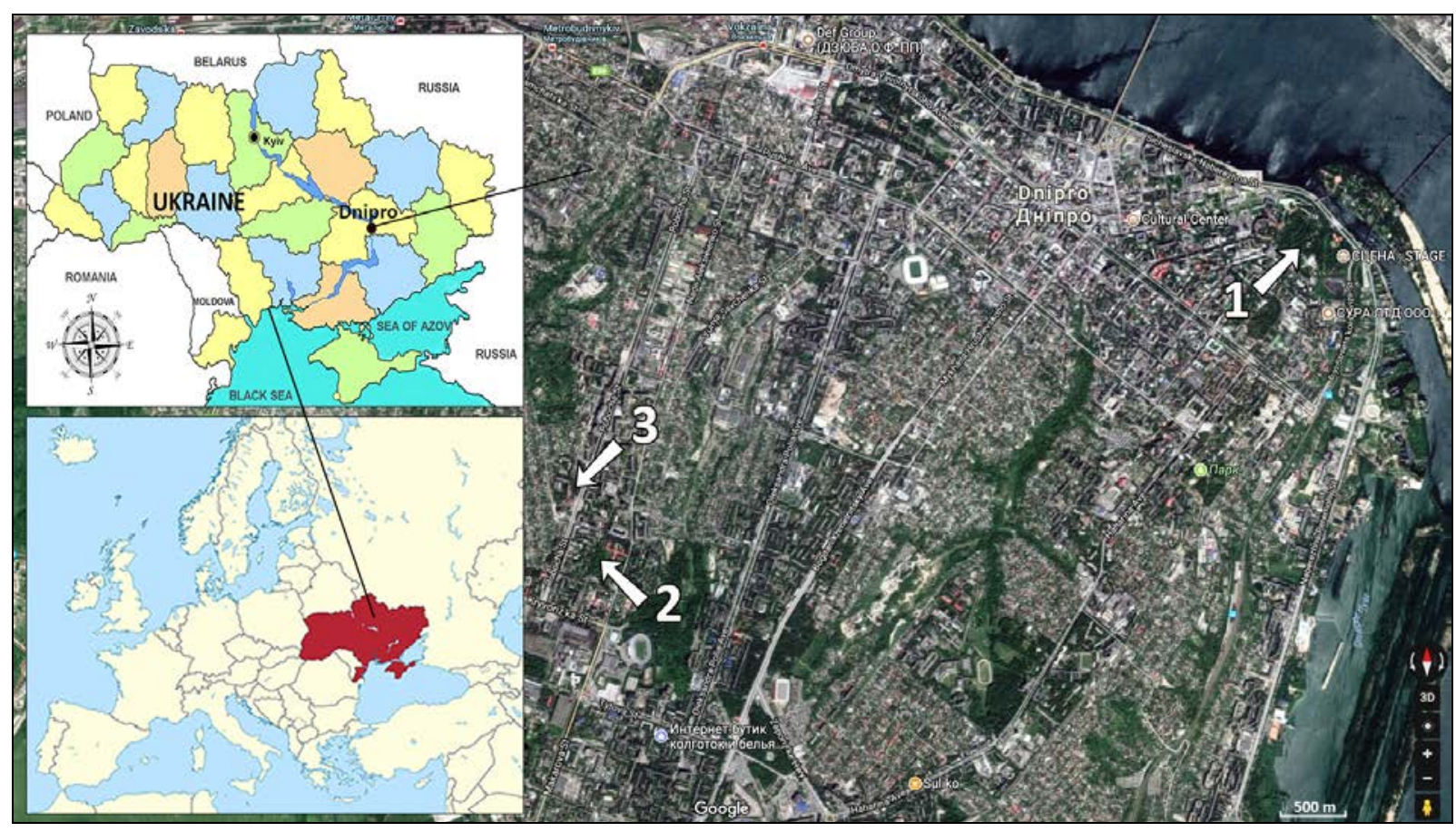

Рис. 1. Локалізація насаджень дуба звичайного на території міста Дніпро: 1 - парк імені Т. Г. Шевченка 3 низьким рівнем забруднення (НP3); 2 - вулиця Д. Кедріна із середнім рівнем забруднення (СР3); 3 - вулиця Робітнича з високим рівнем забруднення (ВРЗ) атмосфери викидами автотранспорту

Таблиця

Зміни вмісту пігментів у листках дерев дуба звичайного залежно від життєвого стану рослин та рівня забруднення повітря викидами автотранспорту $(\mathrm{x} \pm \mathrm{SE})$

\begin{tabular}{|c|c|c|c|c|c|c|}
\hline \multirow{2}{*}{ Пігменти } & \multicolumn{3}{|c|}{ Класи життєвості } & \multicolumn{3}{|c|}{ Рівні забруднення } \\
\hline & $\mathrm{I}, \mathrm{n}=44$ & II, $\mathrm{n}=16$ & III, $\mathrm{n}=12$ & низький, $\mathrm{n}=24$ & середній, $\mathrm{n}=24$ & високий, $\mathrm{n}=24$ \\
\hline Хлорофіл $a$ & $3,95 \pm 0,06^{\mathrm{a}}$ & $2,86 \pm 0,10^{\mathrm{ab}}$ & $2,20 \pm 0,11^{\text {ac }}$ & $2,77 \pm 0,08^{\mathrm{d}}$ & $3,51 \pm 0,09^{\mathrm{de}}$ & $2,72 \pm 0,08^{\mathrm{f}}$ \\
\hline Хлорофіл $b$ & $2,09 \pm 0,06^{\mathrm{a}}$ & $1,50 \pm 0,09^{\mathrm{ab}}$ & $1,65 \pm 0,10^{\mathrm{ac}}$ & $1,69 \pm 0,07^{d}$ & $1,94^{\mathrm{e}} \pm 0,08^{\mathrm{e}}$ & $1,60 \pm 0,09^{\mathrm{ef}}$ \\
\hline Сума хлорофілів $a+b$ & $6,06 \pm 0,12^{\mathrm{a}}$ & $4,33 \pm 0,19^{\mathrm{ab}}$ & $4,00 \pm 0,21^{\text {ac }}$ & $4,48 \pm 0,15^{d}$ & $5,51 \pm 0,18^{\text {de }}$ & $4,39 \pm 0,16^{\mathrm{ef}}$ \\
\hline Хлорофіл $a$ /хлорофіл $b$ & $1,88 \pm 0,04^{\mathrm{a}}$ & $1,90 \pm 0,06^{\mathrm{bc}}$ & $1,33 \pm 0,06^{\mathrm{ac}}$ & $1,68 \pm 0,05^{d}$ & $1,84 \pm 0,06^{\mathrm{e}}$ & $1,72 \pm 0,05^{\mathrm{f}}$ \\
\hline Каротиноїди & $1,17 \pm 0,01^{\mathrm{a}}$ & $0,94 \pm 0,02^{\mathrm{ab}}$ & $0,94 \pm 0,02^{\mathrm{ac}}$ & $0,96 \pm 0,02^{\mathrm{d}}$ & $1,05 \pm 0,02^{\text {de }}$ & $1,03 \pm 0,02^{\mathrm{df}}$ \\
\hline
\end{tabular}

Примітка: * - однакові латинські букви означають статистично незначущі розбіжності середніх у ряді за критерієм Тьюкі (HSD).

Значення співвідношення хлорофіл $a$ / хлорофіл $b$ перебувало практично на одному рівні в листках дуба I і II класів життєвості, а в листках дубів III класу цей показник нижчий за контроль на $29,3 \%\left(\mathrm{~F}=17,87 ; \mathrm{P}<1,4 \cdot 10^{-5}\right)$. Каротиноїди показали найбільший рівень накопичення у здорових рослин дуба (I клас) порівняно 3 пошкодженими на 19,7\% (F = 68,28; $\left.\mathrm{P}<4,1 \cdot 10^{-4}\right)$. Співвідношення хлорофілів $a+b /$ каротиноїди становило 4,6, 4,3 і 4,7 відповідно до I, II і III класів життєвості рослин дуба. Інша картина спостерігається, якщо порівнювати вмісту хлорофілів і каротиноїдів за впливу атмосферного забруднення. Найвищий вміст хлорофілів $a$ i $b$ та їх суми порівняно 3 зоною умовно чистого контролю встановлено для дерев із тери- торії із середнім рівнем забруднення: на 26,7 ( $\mathrm{F}=26,19$; $\mathrm{P}<1,5$ $\left.\cdot 10^{-5}\right), 14,8(\mathrm{~F}=4,21 ; \mathrm{P}<0,019), 23,0 \%\left(\mathrm{~F}=14,08 ; \mathrm{P}<2,6 \cdot 10^{-5}\right)$ відповідно. За високого рівня забруднення атмосфери полютантами спостерігали тенденцію до зниження вмісту хлорофілів $a$ і $b$ та їх суми (на 1,8, 5,3 і 2,0\%, відповідно), а їх співвідношення залишалось практично на рівні контролю. Характер зміни вмісту каротиноїдів у листі дослідних дерев дуба звичайного подібний: на забруднених ділянках у листі більшості дерев спостерігали підвищення їх концентрації, що становило 7,3\% (CP3) і 9,4\% (BP3) порівняно з контролем (F = 7,52, $\mathrm{P}<$ $\left.1,1 \cdot 10^{-3}\right)$. Співвідношення хлорофілів $a+b /$ каротиноїди становило 4,7, 5,2 і 4,3 відповідно до рослин дуба з паркової зони, 
вулиць із середнім та високим рівнем забруднення атмосфери викидами автотранспорту. Для вивчення амплітуди мінливості вмісту пігментів у листках дуба звичайного за дії викидів автотранспорту різної інтенсивності та класами життєвості розраховано коефіцієнт варіації (рис. 2).
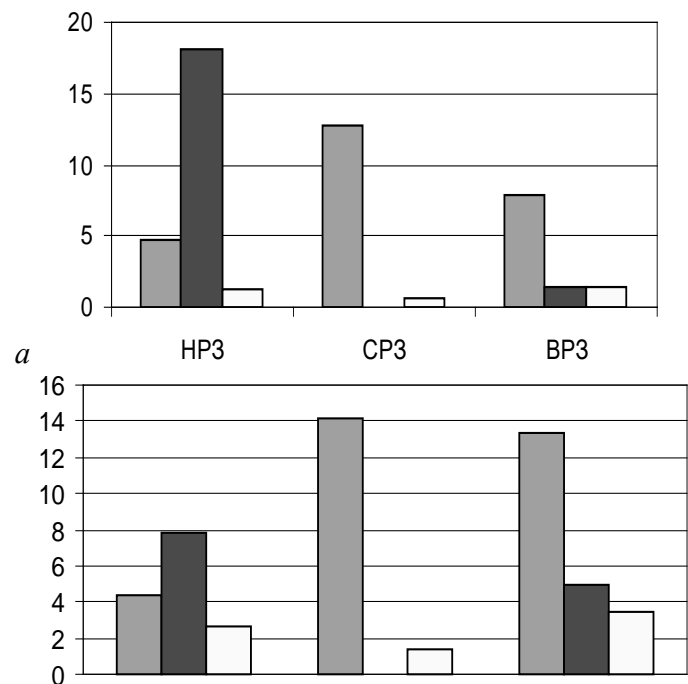

$\sigma$

HP3

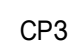

BP3

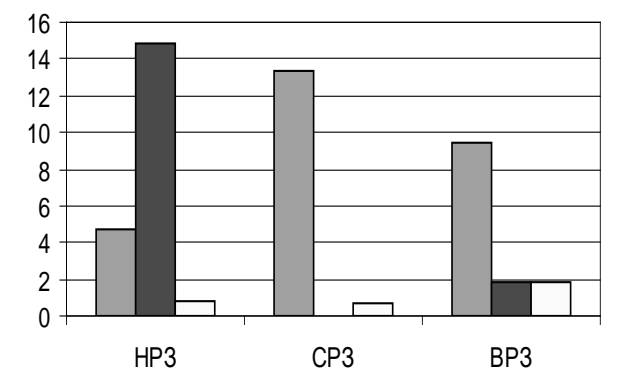

B

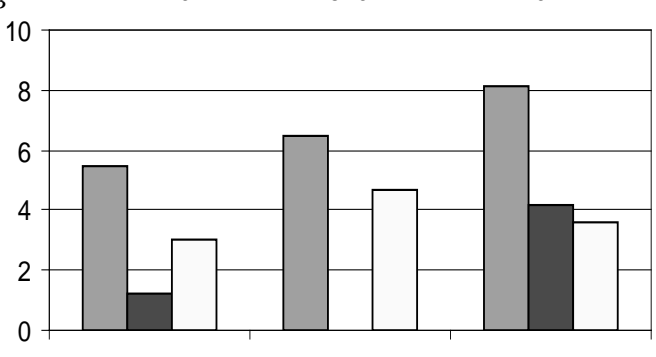

2

HP3

CP3

BP3

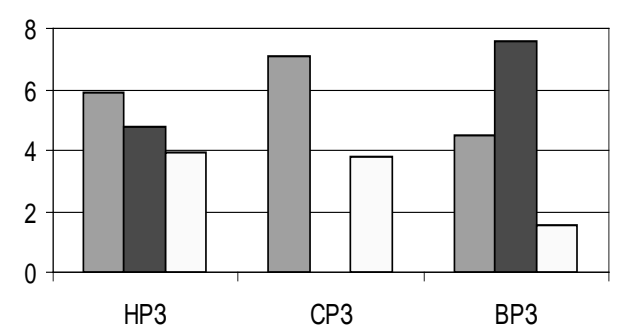

$\partial$

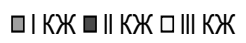

Рис. 2. Варіабельність вмісту пігментів у листках дерев дуба звичайного залежно від життєвого стану рослин та рівня забруднення повітря викидами автотранспорту (V, \%): HP3, CP3, ВР3 - відповідно низький, середній і високий рівні забруднення; I-III: КЖ (класи життєвості); $a$-хлорофіл $a$; $\sigma$-хлорофіл $b$; $в$-хлорофіл $a+b ; 2-$ хлорофіл $a / b ; \partial-$ каротиноїди

Аналіз даних виявив широку амплітуду мінливості вмісту пігментів за класами життєвості. Варіабельність вмісту хлорофілу а в умовах паркової зони складала від 1,25\% (III клас) до
18,10\% (II клас). За дії середнього рівня забруднення - від 0,69\% (III клас) до 12,80\% (I клас), а високого - від 1,36\% (II клас) до 7,95\% (I клас). Таким чином, найбільша мінливість вмісту хлорофілу $а$ встановлена для дерев I і II класів життєвості. Причому у парковій зоні найбільша варіабельність цього параметра притаманна деревам II класу, а в умовах середнього та високого забруднення атмосфери викидами автотранспорту I класу. Така сама закономірність властива показникам вмісту хлорофілу $b$, суми хлорофілів $a+b$ та їх співвідношення $a / b$. Що стосується вмісту каротиноїдів, то для дерев з умовно чистої зони та території із середнім рівнем забруднення виявлено подібну закономірність, у той час як у дуба 3 території з високим рівнем забруднення найвища мінливість установлена для дерев II класу життєвості (7,60\%).

\section{Обговорення}

Газові емісії автотранспорту, до складу яких входить значна кількість важких металів ( $\mathrm{Pb}, \mathrm{Cd}$, Ni та $\mathrm{Zn})$, спричинюють підвищений вміст цих елементів у пробах придорожньої рослинності (Samchuk et al., 2015). Це викликає загальні фізіологічні та біохімічні зміни у рослинах, а з ними - цілу низку ефектів, таких як зміни азотного та білкового метаболізму, інгібування фотосинтезу, порушення руху фотоасимілятів тощо, посилює гальмування росту та розвитку рослин (Торсhij, 2010). Як критерій оцінювання впливу несприятливих умов середовища на деревні рослини використовують вміст пігментів та їх співвідношення (Ricks and Willams, 1975). У цілому вміст хлорофілу $a$ у дуба звичайного вищий за вміст хлорофілу $b$ і складає 52,4-75,0\% від загального вмісту зелених пігментів у всіх проаналізованих листках. Дослідження стану пігментного апарату листків дуба звичайного показали, що вміст хлорофілів $a$ і $b$ інтенсивніше знижується у дерев ослаблених і сильно пошкоджених порівняно зі здоровими, i більшою мірою за високого рівня атмосферного забруднення транспортними викидами. Низка дослідників продемонстрували, що за дії емісій автотранспорту вміст хлорофілів у листках деревних порід часто знижується через поглинання асиміляційними органами рослин важких металів, особливо свинцю, який викликає зміну морфоструктурних та фізіологічних параметрів (Chipilyak and Gryshko, 2014; Prysedsky and Lykholat, 2017; Prysedskyj, 2017).

Залежно від життєвого стану рослин дуба вміст хлорофілу $a$ знижується більше, ніж хлорофілу $b$. Якщо у сильно пошкоджених дерев дуба вміст хлорофілу $а$ знижується на 44,3\% порівняно 3 деревами відносно здоровими, то хлорофілу $b$ на 21,1\%. У дослідженні Korshykov et al. (1995) порівняльним вивченням вмісту хлорофілів у двох контрастних за стійкістю видів кленів показано, що частка хлорофілу $а$ в листках дерев із групи сильно пошкоджених до його вмісту в листках не пошкоджених у клена гостролистого складала $37,4 \%$, а у клена-явора - 50,3\%, для хлорофілу $b$ відповідно 39,3\% і 50,5\%, для каротиноїдів 52,3\% i $67,2 \%$. Таким чином, на відміну від кленів, у листках сильно пошкоджених дерев дуба звичайного суттєвіше знижується вміст хлорофілу $a$. За середнього рівня забруднення відмічається підвищення вмісту хлорофілу $b$ на $14,8 \%$ порівняно $з$ парковою зоною, а в умовах високого рівня - зменшення на 5,3\%. На відсутність чіткої спрямованості у змінах вмісту хлорофілу $b$ за дії викидів автотранспорту у листках Rhus thyphyna вказано у праці Dzhygan (2017), де зазначається, що на близькій відстані від автошляху показники цього параметра зростали, а на віддаленій або зменшувались (25 м), або були на рівні контролю (40 м від автошляху).

Вміст суми хлорофілів у листках дуба звичайного перебував у межах 4,00-6,06 мг/г сирої ваги. За літературними даними, цей показник у різних видів дерев коливається від 0,3 до 5,0 мг/г сирої ваги (Bukharina et al., 2013). У більшості рослин дуба вміст суми хлорофілів був в основному в межах діапазону, за винятком дерев паркової зони I класу життєвості. Значення суми хлорофілів $a+b$ достовірно знижувались у дерев II i III класу життєвості порівняно зі здоровими рослинами на 
28,6\% і 34,0\% відповідно, у той час як за дії емісій автотранспорту нижчі значення параметра властиві деревам I і III класу життєвості. Підвищення суми хлорофілів у дерев II класу життєвості в умовах середнього рівня забруднення атмосфери викидами автотранспорту відбулось за рахунок вищого вмісту хлорофілу $b$.

Як фітоіндикаційний показник використовується співвідношення хлорофілів $a / b$, яке в умовах впливу вихлопних газів автотранспорту у чутливих хвойних порід, у тополі Болле та клена гостролистого зменшувалось, тоді як у стійкого клена явора цей показник мало змінювався (Korshykov, 1995). За цим показником дуб звичайний можна віднести до відносно стійких деревних порід, оскільки, за нашими даними, відношення хлорофіл $a$ / хлорофіл $b$ за дії емісій автотранспорту практично не відрізнялось від значень контрольних зразків. У той же час у дерев сильно пошкоджених спостерігалось суттєве (на 29,3\%) зниження відношення хлорофілів $a / b$. Таким чином, поряд із зменшенням сумарної кількості зелених пігментів у листках дуба звичайного, відношення хлорофілів $a / b$ зберігається практично незмінним навіть за високого рівня забруднення атмосфери емісіями автомобільного транспорту. Хлорофіл $a$ входить до складу реакційних центрів та периферійних антенних комплексів ФС I і ФС II, у той час як хлорофіл $b$ - до світлозбирального комплексу ФС II і постійність цього відношення вказує на незмінність стехіометричного співвідношення між комплексами реакційних центрів фотосистем і світлозбирального комплексу ФС II (Titov, 2007).

У межах однієї моніторингової ділянки залежно від життєвого стану рослин дуба аналізом групових середніх виявлено зниження вмісту каротиноїдів в ослаблених і сильно пошкоджених рослинах. За дії забруднення атмосфери встановлено підвищення цього показника, що узгоджується 3 літературними даними (Favaretto et al., 2011; Chipilyak and Gryshko, 2014). Більша надійність каротиноїдів порівняно $з$ хлорофілом $a$ пов'язана із захисною функцією каротиноїдів у клітині, яка виявляється в інактивації активних форм кисню та тепловому розсіюванні світлової енергії.

Як показник адаптивності рослин до несприятливих умов середовища використовується співвідношення суми хлорофілів до каротиноїдів ( $a+b$ / каротиноїди), яке швидко реагує на зміни довкілля. Volodarets (2011) на деяких видах деревних рослин показано коливання цього співвідношення від 2 до 6 на територіях, де антропогенне навантаження найвище, у той час як у контролі це співвідношення становило 8. Ми встановили, що значення цього параметра варіювало в межах 4,3-4,7 залежно від класу життєвості дерев дуба, а за впливу транспортних емісій цей діапазон складав 4,3-5,2. Такі результати можуть свідчити про стресовий стан рослин дуба, причому як у парковій зоні, так і на забруднених транспортними емісіями територіях міста.

Наші дослідження показали пластичність фотосинтечичного апарату дуба звичайного, особливо у здорових і ослаблених дерев (I і II класи життєвості), в яких відмічається найвища варіабельність вмісту пігментів, у той час як у сильно пошкоджених рослин установлено низьку мінливість вмісту хлорофілів. Ця закономірність збігається з класичними уявленнями про екологічну перевагу варіабельних відповідей для стійкіших у несприятливих умовах довкілля організмів.

\section{Висновки}

У вуличних насадженнях транспортні емісії впливають на функціональний стан дуба звичайного, що підтверджується змінами у складі пігментного апарату листків. У здорових рослин дуба звичайного ці зміни менш критичні порівняно 3 ослабленими та сильно пошкодженими, які зростають у різних умовах забруднення атмосфери транспортними емісіями. Більшу різницю у перебудові пігментного комплексу листків дуба встановлено між групами дерев із різним рівнем життєвого стану. Найвищі показники накопичення пігментів виявлено в умовах середнього, а найнижчі - високого рівня забруднення атмосфери викидами автотранспорту, при цьому вміст хлорофілу $a$ знижується суттєвіше за хлорофіл $b$.

Відношення хлорофіл $a$ / хлорофіл $b$ у дерев дуба звичайного I і II класів життєвості змінюється незначно, що дозволяє рослинам підтримувати стабільність співвідношення між комплексами реакційних центрів фотосистем і світлозбирального комплексу ФС II. Уміст каротиноїдів зменшується в ослаблених і сильно пошкоджених дерев порівняно із здоровими рослинами, а за дії автотранспортних емісій підвищується.

За рядом показників (переважна більшість дерев I і II класів життєвості (84,2\%), підвищення вмісту каротиноїдів, стабільність співвідношення хлорофілів $a / b)$ в умовах вуличних насаджень дуб звичайний можна віднести до стійких. У той же час низькі значення співвідношення суми хлорофілів $a+b$ до каротиноїдів свідчать про стресовий стан рослин дуба незалежно від індексу життєвості та рівня інтенсивності забруднення повітря викидами автотранспорту. Це потребує забезпечення оптимального догляду за ростом і розвитком дерев дуба звичайного в несприятливих умовах міського середовища для підвищення рівня їх життєвості.

\section{References}

Brygadyrenko, V. V. (2016). Evaluation of ecological niches of abundant species of Poecilus and Pterostichus (Coleoptera: Carabidae) in forests of the steppe zone of Ukraine. Entomologica Fennica, 27(2), 81-100.

Bukharyna, I. L., Kuzmin, P. A., \& Gibadulyna, I. I. (2013). Analiz soderzhania fotosinteticheskih pigmentov $\mathrm{v}$ listjah drevesnyh rastenij $\mathrm{v}$ uslovijah gorodskoj sredy (na primere g. Naberezhnii Chelny) [Analysis of the content of photosynthetical pigments in leaves of woody plants in conditions of city environments (on example Naberezhnii Chelny)]. Vestnyk of Udmurtia University. Seria: Biology. Sciences About the Earth, 1, 20-25 (in Russian).

Castro, A. V., de Almeida, A.-A. F., Pirovani, C. P., Graciele, S. M., Reis, G. S. M., Almeida, N. M., \& Mangabeira, P. A. O. (2015). Morphological, biochemical, molecular and ultrastructural changes induced by Cd toxicity in seedlings of Theobroma cacao L. Ecotoxicology and Environmental Safety, 115, 174-186.

Chipilyak, T. F., \& Gryshko, V. N. (2014). Pristosuvannya asimilyatsiynogo aparatu sortiv liliyniku (Hemerocalis L.) do zabrudnennya vazhkimi metalami [Adaptation of assimilative apparatus of plastids of daylily sorts (Hemerocalis L.) towards the pollution by heavy metals]. Biologicheskiy Vestnik Melitopolskogo Gosudarstvennogo Pedagogicheskogo Universiteta imeni Bogdana Hmelnitskogo, 4(2), 83-97.

Dai, Y. J., Shen, Z. G., Liu, Y., Wang, L. L., Hannaway, D., \& Lu, H. F. (2009). Effects of shade treatments on the photosynthetic capacity, chlorophyll fluorescence, and chlorophyll content of Tetrastigma hemsleyanum Dielset Gilg. Environmental and Experimental Botany, 65, 177-182.

Dolhova, L. H., \& Filina, T. V. (2003). Vplyv zabrudnennya hruntiv na stan humusu [Influence of soils contamination on humus state]. Pytannya Bioindykatsiyi ta Ekolohiyi, 8(1), 104-109 (in Ukranian).

Favaretto, V. F., Martinez, C. A., Soriani, H. H., \& Furriel, R. P. M. (2011). Differential responses of antioxidant enzymes in pioneer and late-successional tropical tree species grown under sun and shade conditions. Environmental and Experimental Botany, 70(1), 20-28.

Korshikov, I. I., Kotov V. S., Miheenko I. P., Ignatenko, A. A., \& Chernyishova, L. V. (1995). Vzaimodeystvie rasteniy s tehnogenno zagryaznennoy sredoy. Ustoychivost. Fitoindikatsiya. Optimizatsiya [Interaction of plants with the technogenic polluted environment. Stability. Phytoindication. Optimisation]. Naukova dumka, Kiev (in Russian).

Lykholat, T., Lykholat, O., \& Antonyuk, S. (2016b). Immunohistochemical and biochemical analysis of mammary gland tumours of different age patients. Cytology and Genetic, 50(1), 32-41.

Lykholat, Y. V., Khromykh, N. O., Ivan'ko, I. A., Matyukha, V. L., Kravets, S. S., Didur, O. O., Alexeyeva, A. A., \& Shupranova, L. V. (2017a). Assesment and prediction of the invasiveness of some alien plants under the climatic changes in the steppe Dnieper. Biosystems Diversity, 25(1), 52-59.

Lykholat, Y., Khromykh, N., Ivan'ko, I., Kovalenko, I., Shupranova, L., \& Kharytonov, M. (2016a). Metabolic responses of steppe forest trees to altitude-associated local environmental changes. Agriculture and Forestry, 62(2), 163-171.

Neil, S., Barros, R., Bright, J., Desikan, R., Hancock, J., Harrison, J., Morris, P., Ribeiro, D., \& Wilson, I. (2008). Nitric oxide, stomatal closure, and abiotic stress. Journal of Experimental Botany, 59(2), 165-176. 
Pasichnyy, H. V., \& Serdyuk, S. M. (2002). Dynamika vazhkykh metaliv v hruntovomu pokryvi u zv'yazku z tekhnohennym zabrudnennyam otochuyuchoho seredovyshcha (na prykladi m. Dnipropetrovs'ka) [Dynamics of heavy metals in a soil cover in connection with technogenic environmental contamination (on an example of Dnipropetrovsk sity)]. Ekolohiya i Pryrodokorystuvannya, 4, 111-117 (in Ukrainian).

Pryseds’kyj, J. H., \& Lykholat, Y. V. (2017). Adaptacija roslyn do antropohennych chynnykiv [Adaptation of plants to anthropogenic factors]. Vasyl' Stus DonNU, Vinnytsya (in Ukrainian).

Prysedskyj, Y. (2017). Influence of air pollution by compounds of fluorine, sulphur and nitrogen on changes of peroxidase and polyphenol oxidase activity in the leaves of trees and bushes. Biosystems Diversity, 25(3), 216-221.

Ricks, G. R., \& Williams, R. J. H. (1975). Effects of atmospheric pollution on deciduous woodland. Part 3: Effects on photosynthetic pigments of leaves of Quercus petraea (Mattuschka) Leibl. Environmental Pollution, 8(2), 97-106.

Samchuk, A. I., Grodzinskaya, A. A., \& Vovk, K. V. (2015). Акумуляція макроі мікроелементів у листках різних деревних порід в умовах київського мегаполісу [Research on accumulation of macro- and microelements in leaves of trees in kiev megalopolis]. Ecology and Noospherology, 26, 34-43 (in Ukrainian)

Sehmer, L., Alaoui-Sosse, B., \& Dizengremel, P. (2012). Effect of salt stress on growth and on the detoxifying pathway of pedunculate oak seedlings (Quercus robur L.). Journal of Plant Physiology, 147(1), 144-151.

Stojnić, S., Pekeč, S., Kebert, M., Pilipović, A., Stojanović, D., Stojanović, M., \& Orlović, S. (2016). Drought effects on pedunculate oak (Quercus robur L.) and hornbeam (Carpinus betulus L.) saplings grown in urban area of Novi Sad, Serbia. South-East European Forest, 7(1), 57-63.

Titov, A. F., Talanova, V. V., Kaznina, N. M., Laydinen, G. F. (2007). Ustoychivost rasteniy k tyazhelyim metallam [Stability of plants to the heavy metals]. Karelskiy Nauchnyiy Tsentr RAN, Petrozavodsk (in Russian).

Topchiy, N. M. (2010). Vpliv vazhkih metaliv na fotocintez [Effect of heavy metals on photosynthesis]. Physiologia i Biochimia Kulturnih Rasteniy, 42(2), 95-106 (in Ukrainian).

Vas'kin, R. A., \& Vas'kina, I. V. (2009). Analiz dynamiky zabrudnennya atmosfernoho povitrya Ukrayiny vykydamy avtotransportu [The analysis of dynamics of pollution of atmospheric air of Ukraine motor transportation emissions]. Visnyk KDPU imeni Mykhayla Ostrohrads'koho, Chastyna 58, 109-112.

Volodarets, S. O. (2012). Fitontsidna aktivnist u zv’jazku z vmistom hlorofiliv u listkah derevnih roslin $\mathrm{v}$ urbanizovanomu seredovischi [Phytoncidical activity in connection with the content of chlorofills in leaves of woody plants in urban environment]. Promislova Botanika, 12, 167-171 (in Ukrainian).

Wettstein, D. (1957). Chlorophyll-letale und submikroskopische formwechsel der plastiden. Experimental Cell Research, 12(3), 427-506.

Xu, Z., \& Zhou, G. (2008). Responses of leaf stomatal density to water status and its relationship with photosynthesis in a grass. Journal of Experimental Botany, 59(12), 3317-3325.

Yermishev, O., Lykholat, T., \& Lykholat, O. (2017). Effect of alimentary synthetic estrogen on cell compensatory mechanisms in rats of different ages. Biologia, 63(2), 152-159. 